\title{
ANALISIS FAKTOR MEKANISME KONTROL TERHADAP PELECEHAN ROHANI DALAM GEREJA
}

\author{
Ivan Th. J. Weismann ${ }^{1)^{*}}$ \\ 1)Dosen Sekolah Tinggi Theologia Jaffray \\ *)Penulis Korespondensi: ivanweismann@yahoo.com
}

\begin{abstract}
Abstrak
Tujuan penelitian ini ialah untuk menganalisis sejauh mana faktor mekanisme kontrol terhadap pelecehan rohani terdapat dalam gereja-gereja masa kini. Hasil penelitian ini menunjukkan adanya pengaruh signifikan faktor mekanisme kontrol terhadap pelecehan rohani dalam gereja. Gereja-gereja yang di dalamnya terkandung pelecehan rohani secara potensial menumbuhkan bentuk ketergantungan yang tidak sehat, secara rohani dan jasmani, dengan berfokus pada tema-tema penundukan dan ketaatan kepada mereka yang memiliki otoritas.
\end{abstract}

Kata kunci: pelecehan, rohani, seksual, otoritas, sindiran, kritikan, emosional

The purpose of this research is to analyze the extent to which the control mechanisms for spiritual abuse is in gereja-gereja today. The results show that there is significant impact factors control mechanisms for spiritual abuse in church. Churches that it contains a potentially spiritual abuse fosters an unhealthy form of dependency, spiritually and physically, by focusing on the themes of submission and obedience to those in authority.

Keywords: abuse, spiritual, sexual, authority, sneered, criticism, emotional

\section{Latar Belakang Masalah}

Pelecehan rohani adalah setua agama palsu itu sendiri. Walaupun praktek pelecehan rohani sudah lama ada, namun istilah "pelecehan rohani" dipopulerkan pertama kali oleh Jeff Van Vonderen. David Hanke mengatakan bahwa pelecehan rohani dapat terjadi pada hampir semua struktur organisasi, tetapi dengan struktur hirarkis "top down" (kepemimpinan dari atas ke bawah) adalah yang terutama cocok untuk terjadinya pelecehan rohani secara sistemik. ${ }^{1}$

Oakley mengemukakan konteks penyebab terjadinya pelecehan rohani dalam suatu kelompok gereja yang diantaranya ialah: ${ }^{2}$

\footnotetext{
${ }^{1}$ David Hanke, "Spiritual Abuse," diakses 10 Februari 2017, http://www.watchman.orgiprofIle/abusepro.htm

${ }^{2}$ L. Oakley \& K. K, Breaking the Silence on Spiritual Abuse (New York: Palgrave Macmillan, 2013), 11-12.
} 
Sifat bebas dari kelompok (seperti pada kebanyakan gereja karismatik), penekanan pada kekuasaan, kurang jelasnya struktur kepemimpinan dan akuntabilitas, dan kurangnya transparansi dalam pengambilan keputusan sebagai faktor kausal dalam pengembangan pelecehan rohani dalam suatu denominasi. Konteks penyebab pelecehan rohani juga pada penekanan utama pada pandangan tentang kepemimpinan, bahwa dalam sistem kelompok ini pemimpin tidak dapat ditentang.Penyebab pelecehan rohani adalah seperti yang ditunjukkan Enroth bahwa ada beberapa gereja yang lebih banyak menekankan pada kepemimpinan otoriter, manipulasi, disiplin gereja yang berlebihan dan intimidasi spiritual. Appleton berkomentar bahwa budaya gereja yang bebas memiliki banyak masalah yang paling jelas dalam hal akuntabilitas dan transparansi.

\section{Ron Enroth menjelaskan bahwa:}

Tidak seperti pelecehan fisik yang sering menyebabkan tubuh memar, pelecehan rohani dan pastoral meninggalkan bekas luka pada jiwa dan roh. Pelecehan rohani ini ditimbulkan oleh orang-orang yang diberikan rasa hormat dan kehormatan dalam masyarakat berdasarkan peran mereka sebagai pemimpin agama dan sebagai model otoritas rohani. Otoritas mereka didasarkan pada Alkitab sebagai firman Allah, dan diri mereka dipandang sebagai gembala dengan kepercayaan yang sakral. Tetapi ketika mereka menyalahgunakan kepercayaan itu, melecehkan otoritas mereka dan menyalahgunakan kekuasaan gerejawi untuk mengontrol dan memani-pulasi umat, hasilnya ialah kekacauan besar. ${ }^{3}$

\section{Faktor-Faktor Mekanisme Kontrol Sebagai Pendukung Terjadinya Pelecehan Rohani}

Ron Enroth menyebutkan ada lima faktor mekanisme kontrol sebagai pendukung timbulnya pelecehan rohani yaitu: 1) Kepemimpinan Otoriter tanpa Pengawasan, 2) Kehidupan Berjemaat yang tidak Seimbang, 3) Ancaman berupa Disiplin dan Dikeluarkan dari Persekutuan, 4) Pemutusan Hubungan Pribadi yang Mengganggu Hubungan dalam Kelompok, 5) Penarikan Diri dan Isolasi dari "kelompok/orang luar."

Tujuh faktor mekanisme kontrol sebagai pendukung terjadinya pelecehan rohani menurut Danielle Diew ialah: ${ }^{5}$

${ }^{3}$ Ken Blue, Healing Spiritual Abuse: How to Break Free from Bad Church Experience, (Downers Grove, InterVarsity Press, 1993), 15.

${ }^{4}$ R. M. Enroth, Churches that Abuse (Grand Rapids: Zondervan Publishing House, 1992). Dikutip oleh Rafael Martinez, "How To Spot Religious Abuse," diakses 12 Februari 2017, http://www.spiritwatch.org/idrelab.htm

${ }_{5}^{5}$ Danielle Diew, "Seven Signs of Spiritual Abuse," diakses 12 Februari 2017, http://socyberty.com/paranormal/seven-signs-of-spiritual-abuse/ 
1. Apakah Anda bebas untuk mengekspresikan diri? Apakah setiap aspek kehidupan Anda diminimalkan atau ditolak? 2. Apakah Anda sering jadi korban kambing hitam? Apakah Anda disalahkan atas tindakan orang lain? 3. Apakah Anda dipaksa menyerahkan kemerdekaan atau mengalihkan otoritas atas hidup Anda kepada orang lain? 4. Apakah pengalaman pribadi Anda diejek atau ditertawakan publik? 5. Ketika Anda membicarakan hal-hal pribadi dengan para pemimpin di komunitas Anda apakah mereka mengkhianati kerahasiaan Anda? 6. Apakah Anda dipaksa untuk bertahan pada bentuk-bentuk lain dari pelecehan rohani? 7. Apakah Anda mengalami penghukuman, penghakiman, kritik atau kurangnya privasi?

Enam faktor mekanisme kontrol sebagai pendukung terjadinya pelecehan rohani menurut Lee Grady ialah: 1. Gaya kepemimpinan otoriter. 2. Suasana rahasia. 3 Elitisme rohani. 4 Manipulasi keuangan. 5. Tidak menghormati kebebasan pribadi. 6. Hyper-spiritualitas. ${ }^{6}$

Adapun situasi gereja yang tidak sehat dan melecehkan secara rohani: 1) Kesombongan Institusional, 2) Eksploitatif, 3) Pemimpin-sentris, 4) Manipulatif, 5) Tidak jujur, 6) Orientasi Hukum atau Kinerja, 7) Menghalangi Pertumbuhan Individu. ${ }^{7}$

Faktor mekanisme kontrol sebagai pendukung terjadinya pelecehan rohani menurut Oakley termasuk: memanipulasi dan mengeksploitasi, akuntabilitas yang dipaksakan, sensor atas pengambilan keputusan, peraturan tentang menyimpan rahasia dan menutup mulut, adanya tekanan dalam hal ketaatan, penyalahgunaan kitab suci atau mimbar untuk mengontrol perilaku, tuntutan untuk menjadi patuh dan taat kepada pelaku, sugesti bahwa bahwa pelaku memiliki posisi 'ilahi' dan dikhususkan dari orang lain, hal-hal inilah secara khusus yang menjadi konteks dalam pelecehan rohani. ${ }^{8}$

\section{Metode Penelitian}

Jenis penelitian ini ialah kuantitatif untuk menganalisis sejauh mana faktor mekanisme kontrol mendukung terjadinya pelecehan rohani terjadi dalam gereja. Populasi dan sampel penelitian ini ialah 150 mahasiswa Kristen di kota Makassar yang berasal dari berbagai provinsi di Indonesia. Para mahasiswa tersebut mengisi angket tentang pelecehan rohani yang didasarkan atas pengalaman mereka di gereja asal mereka. Angket ini menggunakan kuesioner yang dibuat oleh Chris Lawson dalam buklet

\footnotetext{
${ }^{6}$ Lee, J. Grady, "6 Warning Signs of Spiritual Abuse," diakses 10 Februari 2017, http://www.charismanews.com/opinion/52762-6-warning-signs-of-spiritual-abuse

7 The Barnabas Ministry, "Characteristics of Unhealthy, Abusive and Cultic Church Environments," diakses 12 Februari 2017, http://www.barnabasministry.com/recovery-characteristics.html

${ }^{8}$ L. Oakley \& K. K. Breaking the Silence on Spiritual Abuse, 21-22.
} 
yang berjudul How to Know If You Are Being Spiritually Abused or Deceived- A Spiritual Abuse Questionnaire. ${ }^{9}$

\section{Analisis Hasil dan Pembahasan}

\section{Mekanisme Kontrol dengan Membatasi Hubungan dengan Orang Lain}

Hasil jawaban angket menunjukkan bahwa 10\% responden bergantung pada "persetujuan" dari pemimpin untuk apa yang mereka lakukan (yaitu apa yang mereka makan, apa yang mereka pakai, di mana mereka pergi, apa yang mereka katakan, dengan siapa mereka harus menghabiskan waktu, dengan siapa mereka harus menikah, musik apa yang harus mereka dengarkan, dan lain-lain). 34\% responden merasa seolah-olah hidup mereka (atau pelayanan mereka) sedang "dikontrol" oleh orang lain. $14 \%$ responden jika mengunjungi gereja lain untuk pernikahan, pembaptisan, pemakaman atau penyerahan bayi, mereka mendapatkan kesulitan. 12\% responden pernah diperintahkan untuk memutuskan semua hubungan dengan masa lalu, dengan kerabat (pasangan, anak, mertua, dan lain-lain) atau dengan teman-teman setelah bergabung dengan kelompok gereja. 12,7\% responden menjawab bahwa kelompok mereka membatasi mereka "mengunjungi" gereja-gereja lain.

Martin dalam bukunya The Heresy of Mind Control, ${ }^{10}$ menjelaskan tentang pembatasan hubungan dengan orang lain. Para pemimpin pelecehan rohani mencegah dialog yang disertai kebebasan berpikir. Para pemimpin pelecehan rohani juga mempromosikan ketakutan yang tidak sehat mengenai bahaya kontaminasi oleh kelompok dari luar. Kelompok pelecehan rohani mendorong atau mengharuskan anggotanya untuk mempertahankan kehidupan secara komunal sehingga pemimpin dapat mengendalikan anggotanya. Anggota harus meminta izin ketika hendak mengunjungi anggota keluarga, atau membuat panggilan telepon kepada kerabat, atau pun mengirim surat kepada teman. Pemimpin memantau setiap percakapan tersebut bahkan berhak untuk menyensor korespondensi anggotanya. Anggota diberitahu oleh pemimpin bahwa mereka belum cukup bijaksana atau cukup dewasa untuk membedakan antara yang berbahaya dan yang tidak berbahaya akibat pengaruh dari luar kelompok. Pemimpin mencegah dialog dan membatasi pertemuan anggota kelompok dengan keluarganya. Sebagai contoh, seseorang yang telah meninggalkan gerejanya, ketika ia masih bergabung dengan gereja

\footnotetext{
${ }^{9}$ Chris Lawson, "How to Know If You Are Being Spiritually Abused or DeceivedA Spiritual Abuse Questionnaire," diakses 10 Februari 2017, http://www.lighthousetrailsresearch.com/blog/?p=21310

10 Stephen Martin, "The Heresy of Mind Control," diakses 12 Februari 2017, https:/libertyforcaptives.com/2012/06/24/mind-field-eight-ways-to-identify-religiousbrainwashing-part-1-of-8/
} 
tersebut, ia diberitahu untuk dapat membedakan antara keluarga "rohani" dan keluarga "alami", dan diminta untuk memutuskan hubungannya dengan anggota keluarga yang meragukan tentang kepemimpinan gembala sidangnya atau gerejanya.

Pembatasan hubungan oleh pemimpin kelompok pelecehan rohani terhadap anggotanya ialah dengan mendefinisikan "kafir" kepada semua orang di luar kelompok mereka. Hasil jawaban angket menunjukkan bahwa 14 responden menjawab bahwa pemimpin mereka meremehkan, mencemooh, atau menunjukkan penghinaan secara konsisten terhadap gereja-gereja Kristen dan lembaga penelitian yang menentang sekte Kristen yang menyimpang. 9,33\% menjawab bahwa kelompok mereka secara konsisten mengutuk orang-orang dan gereja-gereja di luar kelompok mereka sebagai "dari Iblis", "setan", "hamba Iblis", "duniawi", dan lain-lain. 7,33\% responden menjawab bahwa gereja mereka memiliki mentalitas "Kami adalah satu-satunya gereja yang benar."

Stephen Martin mengatakan, kelompok pelecehan rohani terlalu sempit dalam mendefinisikan bahwa "kelompok mereka sendiri sebagai satu-satunya kelompok orang percaya yang sejati di dalam Yesus. Faktanya adalah, bahwa ada banyak orang percaya sejati dalam Yesus 'di luar sana' jika saja mereka mau terbuka dan jujur mendengarkan apa yang dikatakan dan melihat apa yang dilakukan orang-orang percaya 'di luar sana'." Inilah sebabnya mengapa pemimpin pelecehan rohani mencoba untuk mengendalikan anggotanya dengan meminta mereka memutuskan kontak dengan orang lain. ${ }^{l 1}$

\section{Mekanisme Kontrol dengan Membatasi Informasi}

Hasil jawaban angket menunjukkan bahwa 21,3\% responden menjawab bahwa ada tekanan terhadap mereka, dengan cara tertentu, untuk mencegah "informasi dari luar" tentang kelompok mereka. 22\% responden menjawab bahwa mereka mengandalkan sepenuhnya, tanpa pertanyaan, tentang materi literatur dan informasi yang kelompok mereka berikan untuk pertumbuhan rohani mereka. 30,7\% responden menjawab bahwa mereka akan didisiplin jika mereka pernah, setiap saat, mendengarkan, membaca atau melihat materi literatur dan multi-media yang bukan dari berasal dari kelompok, gereja atau organisasi mereka. Bahan dapat mencakup hal seperti buku, jurnal, traktat, majalah, buletin, CD, DVD, kaset audio, video, website, dan lain-lain. Ada 13,3\% menjawab bahwa mereka hanya diperbolehkan menggunakan alat bantu belajar, buku, dan lain-lain yang hanya berasal dari kelompok atau organisasi. 10\% responden menjawab bahwa pemimpin mereka pernah berkomunikasi

"l Stephen Martin, "The Heresy of Mind Control," diakses 12 Februari 2017, https://ibertyforcaptives.com/2012/06/24/mind-field-eight-ways-to-identify-religiousbrainwashing-part-1-of-8/ 
dengan mereka bahwa hanya bahan atau materi organisasi mereka yang berasal dari "Allah" dan/atau hanya kelompok mereka sendiri yang adalah "Organisasi Allah." 5,33\% responden menjawab bahwa pemimpin mereka pernah mengatakan kepada mereka bahwa semua bahan studi Alkitab di luar kelompok mereka dianggap duniawi, buruk, murtad, "setan," atau jahat. 20,7\% responden menjawab bahwa jika mereka kedapatan membaca materi rohani atau penilaian tentang kelompok mereka, yang tidak diterbitkan oleh kelompok mereka, atau organisasi mereka, maka mereka harus didisiplin. 70\% responden menjawab bahwa kelompok mereka mendorong mereka untuk membaca Alkitab secara pribadi, tanpa harus bergantung pada interpretasi pengajaran dalam kelompok mereka.

Kelompok pelecehan rohani yang destruktif memiliki obsesi untuk membatasi pengaruh "duniawi" yang didefinisikan sebagai pengajaran agama lain, dan yang selalu memberikan informasi dan penilaian negatif tentang kelompoknya. Pembatasan informasi dijelaskan oleh Martin dalam bukunya The Heresy of Mind Control, ${ }^{12}$ di antaranya ialah, pemimpin melarang anggota kelompok menonton berita, mendapatkan akses internet, membaca buku-buku non-religius, atau menerima sumber informasi apapun dari orang-orang di luar kelompok. Ketika ada informasi atau ada anggota keluarga yang meragukan atau menyampaikan informasi negatif tentang kelompok, maka pemimpin kelompok merasa perlu untuk secara mendalam membahas informasi itu untuk membuktikan kepada anggota kelompok bahwa informasi tersebut palsu atau tidak Alkitabiah. Berpikir kritis tidak diperbolehkan, dan interpretasi pemimpin untuk setiap masalah disamakan sebagai kebenaran Allah.

Bentuk kontrol informasi yang nyata adalah pengajaran dan pemberitaan firman dari mimbar. Gembala sidang melakukan kontrol dan manipulasi melalui khotbah-khotbah mereka. Tema-tema tertentu yang tersusun secarai teratur di antaranya ialah: perjanjian, otoritas, ketaatan, penundukan diri, melayani, menghormati dan seterusnya. ${ }^{13}$ Ayat-ayat Alkitab yang dikutip untuk mendukung kontrol informasi ini adalah 1 Yohanes 2:15, "Janganlah kamu mengasihi dunia dan apa yang di dalamnya"; Yakobus 1:27, "ibadah yang murni dan yang tak bercacat di hadapan Allah, Bapa kita ialah ...menjaga supaya dirinya sendiri tidak dicemarkan oleh dunia"; dan Matius 16:6, "Waspadalah terhadap ragi orang Farisi."

${ }^{12}$ Stephen Martin, "The Heresy of Mind Control," diakses 12 Februari 2017, https://ibertyforcaptives.com/2012/06/24/mind-field-eight-ways-to-identify-religiousbrainwashing-part-1-of-8/

${ }^{13}$ R. M. Enroth, Churches that Abuse (Grand Rapids: Zondervan Publishing House, 1992), 55-56. 


\section{Mekanisme Kontrol melalui Penggunaan Kekuasaan dengan Posisi Ilahi}

Hasil jawaban angket menunjukkan bahwa 38\% responden dalam segala sesuatu merasa takut kepada pemimpin mereka. 27,3\% responden menjawab bahwa gereja atau kelompok mereka bergantung pada satu pribadi karismatik utama (seperti pemimpin gereja) yang menjadi penentu akhir dalam hal "kebenaran" doktrin. 9,3\% responden menjawab bahwa pemimpin mereka mengklaim dirinya sebagai yang "diurapi," dan memiliki "Jubah Elia," atau memiliki "Otoritas Rasul," dan lain-lain.

Posisi ilahi ini berasal dari gagasan Alkitab tentang otoritas tertinggi, bahwa individu yang terlihat memegang posisi tersebut dipandang sebagai dipilih oleh Allah. Pandangan tentang kepemimpinan dan penetapan ilahi memiliki landasan dalam Kitab Suci. Misalnya, dalam Mazmur 105:15 pemimpin disebut sebagai 'orang yang diurapi' Allah. Ward menunjukkan bahwa individu dalam konteks pelecehan rohani percaya bahwa para pemimpin telah 'ditempatkan oleh Allah untuk berada di atas posisi mereka'. Dalam beberapa denominasi gereja ada keyakinan yang kuat bahwa Allah masih berbicara secara langsung kepada individu. Oleh karena itu orang lain tidak boleh mempertanyakan perkataan yang dari Allah yang diterima oleh individu itu dan dalam pengalaman pelecehan rohani setiap informasi diciptakan dengan tujuan memanipulasi atau mengontrol orang lain. ${ }^{14}$

\section{Mekanisme Kontrol melalui Penggunaan Kekuasaan dengan Otoritas Ilahi}

Ada gembala sidang berkata kepada jemaat mereka, "Karena saya gembala, Anda harus mengikuti saya." Tuntutan mereka tidak didasarkan pada kebenaran atau arahan Tuhan terhadap kepemimpinan mereka melainkan pada jabatan atau gelar mereka. Itu adalah dasar otoritas yang palsu. Ada pula pemimpin agama lain yang mengatakan, "Karena saya memiliki gelar Ph.D., Anda harus memerhatikan kata-kata saya dengan serius." 15

Paus di Roma menuntut dirinya sebagai yang tidak dapat dipersalahkan, hal ini didasarkan pada bahwa ia adalah pengganti Rasul Petrus. Padahal Petrus adalah satu-satunya orang yang pernah Yesus sebut sebagai "Setan", ia juga murid yang menyangkal Yesus tiga kali, Petrus juga terbukti keliru dalam perdebatan dengan Paulus (Galatia 2).

Menurut Blue, otoritas yang didasarkan pada posisi, gelar atau jabatan adalah palsu. Satu-satunya otoritas yang Allah akui dan yang kita harus tunduk adalah kebenaran. Orang yang mengambil untuk diri mereka sendiri "kursi otoritas" sering merasa perlu untuk memperindah jabatan, posisi atau gelar mereka dengan tambahan "klaim khusus."

\footnotetext{
${ }^{14}$ Oakley, 48.

${ }^{15}$ Ken Blue, Healing Spiritual Abuse: How to Break Free from Bad Church Experience, 41.
} 
Mereka menunjukkan bahwa mereka memiliki "panggilan unik," "kemampuan atau karunia yang satu-satunya," yang hanya ada pada diri mereka, "pengalaman luar biasa" atau "wahyu kenabian" yang semuanya itu mereka gunakan untuk mendukung jabatan atau posisi mereka. Padahal tak satu pun dari klaim khusus ini ada hubungannya dengan otoritas rohani yang sejati. ${ }^{16}$

Hasil jawaban angket menunjukkan bahwa 25,3\% responden menjawab pemimpin utama, atau para pemimpin di gereja mereka atau kelompok selalu bersikeras bahwa para pemimpin itu selalu benar. 8,67\% responden menjawab kelompok, gereja atau gerakan mereka memakai gaya kepemimpinan "Musa/Harun" (Teokrasi Perjanjian Lama) di mana gembala sidang / pemimpin mendengar firman Allah secara langsung dari Allah seperti "Musa" (tidak seperti model kepemimpinan para penatua yang ditekankan dalam Perjanjian Baru). 17,3 responden menjawab pemimpin mereka atau asistennya pernah berbohong kepada mereka atau mencoba untuk menutupi kebohongan pemimpin lain.

Tipuan yang digunakan untuk menjaga pemimpin agar tetap bertengger di kursi Musa ialah merujuk kepada diri mereka sebagai "yang diurapi Tuhan." Menurut Blue, ini berarti bahwa mereka telah dipilih dan dianugerahi karunia-karunia oleh Allah dan harus diperlakukan dengan penghormatan khusus. Perintah Perjanjian Lama menyebutkan "jangan menjamah orang yang diurapi Tuhan" digunakan untuk melindungi para pemimpin dari pengujian atau kritik. Frasa ini, yang berasal dari 1 Tawarikh 16:22 dan Mazmur 105:15, diambil ke luar dari konteks dan dipelintir untuk memenuhi kebutuhan. Ketika Daud mengucapkan katakata ini dia memperingatkan anak buahnya untuk tidak membunuh Raja Saul, yang telah diurapi dengan minyak dan Roh Kudus. ${ }^{17}$

Peringatan Daud untuk tidak membunuh raja tidak ada hubungannya dengan perlakuan terhadap pemimpin gereja pada masa kini. Sistem klas dalam Israel kuno, dengan hierarkinya ialah raja-raja, nabi dan imam, telah dihapuskan dalam Perjanjian Baru. Hanya ada satu Raja, dan semua umat Allah yang lainnya ialah imam yang diberi karunia untuk bernubuat. Pengurapan rohani yang dicurahkan kepada raja, nabi dan imam di Perjanjian Lama sekarang dicurahkan pada semua umat Allah. Ada upaya dari beberapa pemimpin gereja membuat klaim tentang adanya pengurapan khusus hanya pada diri mereka dengan begitu mereka menciptakan hierarki dalam gereja, sehingga mereka dapat lebih mudah mengontrol jemaat yang di bawah mereka. Dengan sistem hierarki itu mereka juga dapat mempertahankan diri mereka terhadap setiap orang yang mencoba menantang mereka. ${ }^{18}$

\footnotetext{
${ }^{16}$ Blue, 42.

17 Blue, 43.

${ }^{18}$ Blue, 43.
} 


\section{Mekanisme Kontrol melalui Mendiskreditkan Pribadi}

Hasil jawaban angket menunjukkan bahwa 22\% responden menjawab jika mereka menanyakan pertanyaan yang valid tentang kebijakan kelompok, ini akan membuat masalah dalam hubungan dengan para pemimpin. $7,3 \%$ menjawab kelompok mereka menggunakan cara "mempermalukan seseorang di muka umum" kepada individu dan/atau keluarga. 17,3\% responden menjawab mereka pernah dihukum atau dilecehkan karena cara berikut: secara fisik dilecehkan, dipermalukan di muka umum secara lisan, tidak diajak ngomong, dilecehkan dengan kode ("pandangan") main mata, diperas secara finansial dan sebagai hasilnya mereka menderita dalam hal keuangan, pelecehan seksual dengan cara apapun, dimanipulasi secara emosional, sengaja dikhianati, sindiran seksual, dan lain-lain.

Individu dalam kelompok pelecehan rohani sering dilabel sebagai 'pemberontak'. Mendiskreditkan pribadi ditujukan kepada individu yang memutuskan untuk meninggalkan gereja. Menurut Oakley ada dua cara mendiskreditkan pribadi sebagai metode kontrol. Pertama, orang-orang di dalam gereja didorong untuk memiliki persepsi 'pemberontak' terhadap individu yang didiskreditkan atau dilabel dan persepsi ini memimpin pada tidak adanya keinginan untuk melakukan kontak pribadi pada individu itu setelah individu itu meninggalkan gereja. Cara kontrol ini memperkuat isolasi eksternal kepada anggota gereja. ${ }^{19}$

Cara kedua tentang penggunaan mendiskreditkan pribadi yang meninggalkan gereja menurut Oakley ialah bahwa mendiskreditkan pribadi dilihat sebagai metode untuk mengontrol perilaku individu yang menjadi anggota dalam gereja dan juga menjadi suatu metode sensor atas ketidakpatuhan dari anggota jemaat. Mendiskreditkan pribadi dialami sebagai serangan atas pribadi. Meskipun mendiskreditkan pribadi itu dialami secara pribadi, namun itu adalah bagian dari sistem dalam kelompok pelecehan rohani karena terjadi di bawah aturan interaksi kelompok itu. Jika seorang individu tidak patuh pada pemimpin atau kelompok, apalagi jika individu itu sampai meninggalkan gereja, sanksinya ialah mendiskreditkan orang itu dan informasi mendiskreditkan ini disebarluaskan untuk dapat melindungi pelaku pelecehan rohani dari penyelidikan atas perbuatan pelecehan yang dilakukannya. Konsekuensi dari kontrol yang dilakukan dalam kelompok pelecehan rohani adalah ketidakberdayaan orang-orang dalam sistem pelecehan rohani atas apa yang dialaminya. ${ }^{20}$

\footnotetext{
${ }^{19}$ Oakley, 41.

${ }^{20}$ Oakley, 41.
} 


\section{Mekanisme Kontrol melalui Komitmen Tinggi pada Pemimpin Pelecehan Rohani}

Hasil jawaban angket menunjukkan bahwa $6 \%$ responden menjawab kelompok mereka mengambil "sumpah" atau menyuruh mereka berkomitmen untuk harapan atau keinginan yang tidak realistis. 8,67\% responden menjawab pemimpin mereka pernah menyuruh dengan nada "keras" atau mereka pernah merasa diperlakukan seperti binatang yang "Dipaksa dengan keras." 2,67\% menjawab gereja, kelompok atau organisasi mereka menyuruh bekerja sampai kurang waktu untuk tidur, mengalami dehidrasi, visualisasi, mengkonsumsi vitamin, menggunakan suntikan, dan lain-lain sebagai sarana untuk menjadi lebih "rohani". 25,3\% responden menjawab pemimpin atau kelompok membuat mereka merasa seolah-olah mereka tidak bisa datang dan pergi sesukamu (misalnya mereka merasa seolah-olah mereka diharapkan untuk mengikuti semua atau sebagian besar pertemuan dalam kelompok).

Kelompok pelecehan rohani sering mempertahankan kontrol atas pengikut mereka dengan membuat mereka kelelahan melalui berbagai kegiatan keagamaan seperti doa, studi Alkitab, persekutuan yang wajib, dan pengarahan-pengarahan dengan durasi waktu yang lama. Semua kegiatan ini menjadi beban yang berkaitan dengan keselamatan jiwa dan juga adalah peraturan buatan manusia.

Tuntutan untuk berkomitmen secara berlebihan adalah kunci dari sistem pelecehan rohani. Komitmen tingkat tinggi dan berkelebihan itu dijelaskan Oakley sebagai berikut: Anggota gereja diharapkan untuk senantiasa meningkatkan tingkat komitmennya dan tingkat layanannya yang sering diartikan dengan menunjukkan kehadiran pada semua pertemuan yang diadakan. Tingkat komitmen kepada gereja sering disamakan dengan komitmen pribadi individu terhadap pelaku pelecehan dan sering dijadikan faktor yang menentukan dalam pemberian promosi atau peningkatan posisi individu dalam gereja. Individu yang patuh hingga mencapai standar komitmen yang tinggi diberi upah dan digambarkan sebagai yang berkenan bagi oleh Allah. Mereka adalah orang khusus yaitu yang secara khusus diurapi dan diasingkan. Mereka adalah umat Allah yang berguna bagi Allah. ${ }^{21}$

Mekanisme Kontrol dengan Menggunakan Rasa Takut, Rasa Bersalah, dan Ancaman

Gereja pelecehan rohani pada masa lalu dan sekarang, ditandai oleh kepemimpinan yang memaksa dan berorientasi kontrol. Para pemimpin ini menggunakan rasa bersalah, rasa takut, dan intimidasi untuk memanipulasi anggota dan menjaga anggota untuk tetap dalam kendali mereka. Pemimpin pelecehan rohani dalam melakukan pelecehan memanfaatkan perasaan universal rasa malu dan rasa bersalah. Semua

\footnotetext{
${ }^{21}$ Oakley, 33.
} 
orang lahir ke dunia sebagai orang berdosa. Karena itu semua orang tahu secara intuitif bahwa ia selalu gagal untuk mencapai kekudusan.

Hasil jawaban angket menunjukkan bahwa 12,7\% responden menunjukkan bahwa kelompok mereka memiliki kebijakan yang memungkinkan pemimpin untuk menggunakan ancaman, tekanan untuk kepatuhan, suap, pelecehan verbal, dan lain-lain. 24,7\% responden menjawab gereja atau kebijakan kelompok mereka tentang "disiplin" adalah ekstrim. 16\% responden menjawab kebijakan kelompok mereka tentang "disiplin" menjadi berbahaya, ilegal, atau menjadi pelecehan dengan cara tertentu. $21,3 \%$ responden menjawab ada saat di mana terdapat jumlah tertinggi tentang orang yang meninggalkan gereja atau kelompok mereka. 63,3\% responden menjawab mereka sering mendengar cerita tentang perselisihan, kepahitan dan kontroversi dalam kelompok mereka atau kepemimpinan kelompok mereka. 8\% responden menjawab mereka mengalami kekejaman atau sikap kasar dari para pemimpin di gereja atau kelompok mereka. 19,3\% responden menjawab mereka mengalami pelecehan dengan cara tertentu, seperti mereka ditakuttakuti, takut atau stres ketika akan meninggalkan kelompok, gereja atau organisasi mereka. 28,7\% responden menjawab mereka takut jika mereka membuat "pilihan yang salah" karena pemimpin mereka akan menghukum mereka.

Mekanisme kontrol dengan menggunakan rasa takut, rasa bersalah dan intimidasi dijelaskan Enroth berikut ini. ${ }^{22}$

Pengikut dituntun untuk berpikir bahwa tidak ada gereja lain yang sama sekali sama seperti gereja mereka dan bahwa Allah telah mengasingkan orang-orang yang tergabung dalam gereja mereka untuk tujuan khusus. Gereja-gereja lainnya di antaranya seperti gereja injili yang lebih tradisional diremehkan. Pengalaman kehidupan rohani yang subjektif lebih ditekankan dan perbedaan pendapat tidak diberi kesempatan untuk didiskusikan. Semua bidang kehidupan anggota sedapat mungkin berada dalam pengawasan. Gereja pelecehan rohani juga menerapkan aturan dan legalisme yang berkelebihan. Anggota jemaat yang tidak bersedia mengikuti aturan atau dianggap sebagai ancaman sering ditangani dengan kekerasan. Pengucilan menjadi alat disiplin yang lazim dilakukan. Bagi mereka yang telah memutuskan untuk meninggalkan gereja, tidak akan mungkin dapat kembali lagi ke gereja yang telah ditinggalkan itu.

\section{Mekanisme Kontrol melalui Penolakan terhadap Akuntabilitas}

Hasil jawaban angket menunjukkan bahwa 70,7\% responden menjawab bahwa mereka diperbolehkan untuk menanyakan dan mengajukan pertanyaan tentang bagaimana uang ditangani, ke mana uang 
itu dibelanjakan dan siapa yang bertanggung jawab dengan keuangan gereja mengetahui kelompok mereka. $10 \%$ responden menjawab kelompok mereka merahasiakan tentang di mana dana keuangan disalurkan dan bagaimana uang dibelanjakan. 8,67\% responden menjawab jika mereka menanyakan tentang siapa yang menghitung dan menangani keuangan, maka pemimpin mereka menunjukkan penghinaan terhadap mereka atau memandang mereka dengan kecurigaan. 7,33\% responden menjawab jika kelompok mereka adalah gereja, ketika uang diterima, hanya satu orang atau salah satu pasangan suami istri yang menghitung dan menangani semua keuangan. 6,67\% responden menjawab mereka pernah diberitahu oleh pemimpin mereka bahwa tidak perlu ada tim pengawas keuangan. 4\% responden menjawab jika kelompok mereka adalah gereja, ketika ada uang yang diterima, para pemimpin menghindari melaporkan dokumen pajak tahunan. 9,33\% responden menjawab ketika uang yang diterima melalui persembahan dan/atau dikumpulkan melalui kotak persembahan, mereka melihat bahwa tidak ada akuntabilitas atau pengawasan dalam penghitungan, pengolahan dan menyimpan dana yang ada. $8 \%$ responden menjawab jika mereka pernah bertanya tentang prosedur akuntabilitas keuangan di gereja, kelompok atau organisasi mereka, pemimpin mereka menunjukkan pembelaan diri dan menantang mereka.

Menjadi akuntabel bagi orang lain adalah hal yang alkitabiah (Efesus 5:21). Oakley menjelaskan bahwa akuntabel ialah:

Setiap orang yang mendapat kepercayaan dari orang lain harus rela menerima orang lain itu sebagai teman yang mengkritik dan memberikan tuntunan baginya. Dalam konteks pelecehan rohani ada perubahan terhadap akuntabilitas yang mengandung pengertian, seorang teman yang peduli, kritis, dan yang memberi komentar pada isu-isu yang dipilih untuk berbagi, berubah menjadi akuntabilitas yang melihat orang lain sebagai individu yang selalu mau tahu dan menghakimi setiap bidang kehidupannya, dengan mengatakan bahwa "saya merasa diteliti, diperiksa dan diselidiki. Setiap langkah yang saya ambil tampaknya selalu diawasi, dinilai dan dihakimi orang lain." Pelaku pelecehan rohani tidak bersedia memiliki akuntabilitas oleh anggota gereja, tetapi anggota gereja dituntut harus memiliki akuntabilitas terhadap pelaku pelecehan rohani dalam hal penggunaan waktu dan segala keputusan yang dibuat. ${ }^{23}$

\section{Mekanisme Kontrol melalui Penolakan terhadap Pemikiran Kritis}

Hasil jawaban angket menunjukkan bahwa 15,3\% responden menjawab mereka merasa bahwa kelompok mereka memelintir dan salah menerapkan ayat-ayat Alkitab. 40,7\% responden menjawab kelompok

\footnotetext{
${ }^{23}$ Oakley, 52.
} 
atau gereja "mengalegorisasikan" dan "merohanikan" Alkitab dari pada menggunakan standar yang diakui secara internasional yaitu pendekatan gramatikal, literal, dan historis untuk menafsirkan Alkitab, seperti yang mereka lakukan di sekolah Alkitab resmi. 30\% responden menjawab mereka dikatakan atau didikte tentang apa yang harus mereka percayai. $10,7 \%$ responden menjawab mereka dipandu dalam mempelajari Alkitab dan pada saat yang sama tidak diperbolehkan untuk mempelajari Alkitab secara pribadi, terpisah dari materi yang disediakan dalam kelompok mereka. 14,7\% responden menjawab pemimpin mereka mengklaim "Pewahyuan Baru," atau "Perkataan langsung dari Allah" secara khusus diberikan padanya. $12,7 \%$ responden menjawab pemimpin mereka menjauhkan atau menghindari memberikan kepada mereka dan kelompok mereka "Pernyataan Keyakinan" atau "Pernyataan Iman" yang tertulis seperti Pengakuan Iman Rasuli. 16\% responden menjawab sulit untuk mendapatkan jawaban secara langsung dari pemimpin kelompok mengenai pengajaran kelompok. 32,7\% responden menjawab kelompok mereka menjaga kerahasiaan tentang beberapa pengajaran, praktik pelayanan atau pertemuan. $13,3 \%$ responden menjawab pemimpin dalam kelompok atau gereja terdiri dari orang-orang "yes men" yang hanya mengikuti, tunduk, dan melaksanakan hasrat dan keinginan satu orang. $42,7 \%$ responden menjawab jika mereka mengunjungi para pemimpin dan mempertanyakan kepada mereka mengenai nubuat palsu yang telah mereka buat, atau ajaran palsu yang mereka telah ajarkan, mereka pikir para pemimpin itu akan marah, jengkel atau frustrasi karena mereka datang untuk menunjukkan kesalahan pemimpin mereka.

Dalam gereja pelecehan rohani diajarkan bahwa gembala sidang diangkat oleh Allah untuk memegang otoritas rohani secara mutlak atas umat mereka. Mereka dipanggil, dilengkapi dan ditopang oleh Allah, dan Allah saja yang dapat mengajukan pertanyaan kepada mereka atau meminta pertanggungjawaban kepada mereka. Pengikut harus menundukkan diri kepada mereka tanpa pertanyaan. Alkitab tidak mengajarkan demikian.

Pengikut dari pemimpin yang menolak pemikiran kritis menjadi bingung tentang apa yang berasal dari Allah dan apa yang berasal dari pemimpin. Garis pemisah menjadi kabur. Sejak pemimpin mengklaim bahwa hanya ia yang dapat mengatakan kepada kelompok tentang apa yang Allah inginkan mereka ketahui, pengikut harus meninggalkan pemikiran kritis dan menerima tanpa klaim perkataan pemimpin. Pemimpin membajak pikiran pengikutnya dan mempromosikan lingkungan ketergantungan total dan perbudakan mental. Ketika sebuah kelompok menerima klaim seorang pemimpin bahwa ia berbicara untuk Allah dan bahwa pendapatnya adalah perkataan Allah sendiri, maka halhal buruk dapat terjadi. 
Kelompok agama totaliter mencegah berpikir kritis dengan melabel pertanyaan penanya sebagai "tidak tunduk," "sombong," atau "berasal dari setan." Mereka biasanya curiga pada sumber-sumber kebenaran lain tentang Alkitab, seperti buku tafsiran, software Alkitab, atau kelas teologia. "Jangan buang waktu Anda dengan sekam ini," mereka mengatakan. "Jadilah seorang yang hanya memiliki 'satu-Kitab' yaitu belajar hanya Alkitab saja dan pastikan hanya mendengarkan khotbah pemimpin sebagai otoritas final."

Meskipun hal ini mungkin terdengar aneh bagi orang-orang yang datang dari latar belakang berpikir bebas di mana diskusi diberi peluang dan pemimpin adalah orang yang rendah hati dan terbuka, namun masih banyak ditemukan ada gereja yang menganggap pemikiran kritis adalah jahat. Para penanya selalu dijawab dengan pernyataan seperti "Jangan menyebabkan perpecahan," atau "Milikilah roh yang mau diajar," atau "percaya saja."

Sebagai catatan: ini bukan untuk mengatakan bahwa gembala sidang dan pemimpin rohani tidak bisa mengklaim bahwa ia berbicara bagi Allah ketika memberitakan firman-Nya. Intinya di sini adalah bahwa para pemimpin pelecehan rohani membuat interpretasi pribadi mereka terhadap kitab suci yang disamakan sebagai kitab suci, mereka membuat wahyu pribadi dari Allah sama dengan kitab suci, dan mereka membuat pendapat pribadi tentang masalah yang diperdebatkan sama dengan hukum ilahi. Dan mereka menggunakan semua metode ini untuk memanipulasi pengikutnya untuk melakukan apa yang pemimpin inginkan. Pemimpin seperti ini mempromosikan diri mereka sebagai utusan Allah yang tidak dapat dipertanyakan dan yang pendapatnya selalu benar dan tidak dapat salah. Dengan demikian, siapa pun yang tidak setuju dengan mereka adalah jahat, sombong dan tidak tunduk. Rasul Paulus meyakinkan jemaat untuk dapat membedakan antara pendapat pribadinya dan wahyu ilahi (lihat 1 Kor. 7).

\section{Kesimpulan Analisis Data Penelitian}

Hasil penelitian ini ialah persentase tinggi untuk faktor mekanisme kontrol terhadap pelecehan rohani dalam gereja ialah pada faktor mekanisme kontrol melalui membatasi hubungan dengan orang lain: 34\% responden merasa seolah-olah hidup mereka (atau pelayanan mereka) sedang "dikontrol" oleh orang lain. Faktor mekanisme kontrol melalui membatasi informasi: $30,7 \%$ responden menjawab mereka akan didisiplin jika pernah, setiap saat, mendengarkan, membaca atau melihat materi literatur dan multi-media yang bukan berasal dari gereja mereka. Faktor mekanisme kontrol melalui penggunaan kekuasaan dengan posisi ilahi: $38 \%$ responden menjawab dalam segala sesuatu merasa takut kepada pemimpin mereka. 
Faktor mekanisme kontrol melalui penggunaan kekuasaan dengan otoritas ilahi: $25,3 \%$ responden menjawab para pemimpin di gereja mereka selalu bersikeras bahwa mereka itu selalu benar. Faktor mekanisme kontrol melalui mendiskreditkan pribadi: 17,3\% responden menjawab mereka pernah dihukum atau dilecehkan dengan cara berikut: Secara fisik dilecehkan, dipermalukan di muka umum secara lisan, tidak diajak ngomong, dilecehkan dengan kode ("pandangan") main mata, diperas secara finansial dan sebagai hasilnya mereka menderita dalam hal keuangan, pelecehan seksual dengan cara apapun, dimanipulasi secara emosional, sengaja dikhianati, sindiran seksual, dan lain-lain. Faktor mekanisme kontrol melalui komitmen tinggi: $25,3 \%$ responden menjawab pemimpin atau kelompok membuat mereka merasa seolah-olah mereka tidak bisa datang dan pergi sesukanya (misalnya mereka merasa seolaholah mereka diharapkan untuk mengikuti semua atau sebagian besar pertemuan dalam kelompok). Faktor mekanisme kontrol dengan menggunakan rasa takut, rasa bersalah dan ancaman: 19,3\% responden menjawab mereka mengalami pelecehan dengan cara tertentu, seperti mereka ditakut-takui, takut atau stress ketika akan meninggalkan gereja mereka.

Faktor mekanisme kontrol melalui penolakan terhadap akuntabilitas: 10\% responden menjawab kelompok mereka merahasiakan tentang di mana dana keuangan disalurkan dan bagaimana uang dibelanjakan. Faktor mekanisme kontrol melalui penolakan terhadap pemikiran kritis: 42,7\% responden menjawab jika mereka mengunjungi para pemimpin dan mempertanyakan kepada mereka mengenai nubuat palsu yang telah mereka buat, atau ajaran palsu yang mereka telah ajarkan, mereka pikir para pemimpin itu akan marah, jengkel atau frustrasi karena mereka datang untuk menunjukkan kesalahan pemimpin mereka.

\section{Kesimpulan}

Gereja-gereja yang di dalamnya terkandung pelecehan rohani secara potensial menumbuhkan bentuk ketergantungan yang tidak sehat, secara rohani dan jasmani, dengan berfokus pada tema-tema penundukan dan ketaatan kepada mereka yang memiliki otoritas. Mereka menciptakan kesan bahwa seseorang tidak akan menemukan jalan mereka melalui likuliku kehidupan tanpa banyak arahan yang tegas dari mereka yang berada di puncak kepemimpinan.

Banyak orang Kristen jatuh ke dalam perangkap mekanisme kontrol karena ia menyerahkan dirinya untuk bertumbuh dalam kelompok yang menawarkan rasa aman dan solusi semu untuk semua masalah, akibatnya ia rentan terhadap pelecehan rohani. Jika seseorang menghargai otonomi rohaninya, ia harus menolak setiap ajaran yang mempertanyakan atau 
meragukan peran Kristus sebagai satu-satunya perantara antara Allah dan manusia. Tidak ada seorang Kristen pun yang dipanggil untuk memberikan ketaatan tanpa pertanyaan kepada seseorang manapun.

Seorang petobat baru akan mendapat peneguhan tentang kemerdekaan dalam hidup yang baru di dalam Kristus. Ironisnya anggota gereja yang mengandung pelecehan rohani menyatakan bahwa mereka telah melepaskan kemerdekaan mereka ketika menjadi anggota gereja tersebut. Mereka justru menemukan diri mereka berada dalam perbudakan mekanisme kontrol pemimpin dan kelompok pelecehan rohani, dan bukannya kebebasan yang sejati, atau dengan kata lain, menyerahkan diri mereka dalam kekanak-kanakan rohani dan ketergantungan daripada membawa diri mereka dalam pertumbuhan.

\section{Kepustakaan}

Blue, Ken. Healing Spiritual Abuse: How to Break Free from Bad Church Experience. Downers Grove, InterVarsity Press, 1993.

Diew, Daniel. "Seven Signs of Spiritual Abuse." Diakses 12 Februari 2017, http://socyberty.com/paranormal/seven-signs-of-spiritual-abuse/

Enroth, R. M. Churches that Abuse. Grand Rapids: Zondervan Publishing House. 1992.

Grady, Lee, J. “6 Warning Signs of Spiritual Abuse.” Diakses 10 Februari 2017, http://www.charismanews.com/opinion/52762-6-warningsigns-of-spiritual-abuse

Hanke, David. "Spiritual Abuse." Diakses 10 Februari 2017, http://www.watchman.orgiprofIle/abusepro.htm

Lawson, Chris. "How to Know If You Are Being Spiritually Abused or Deceived- A Spiritual Abuse Questionnaire." Diakses 10 Februari 2017, http://www.lighthousetrailsresearch.com/blog/?p=21310

Martin, Stephen. "The Heresy of Mind Control." Diakses 12 Februari 2017, https://ibertyforcaptives.com/2012/06/24/mind-field-eightways-to-identify-religious-brainwashing-part-1-of-8/

Martinez, Rafael. "How To Spot Religious Abuse." Diakses 12 Februari 2017, http://www.spiritwatch.org/idrelab.htm

Oakley, L. \& K. K. Breaking the Silence on Spiritual Abuse. New York: Palgrave Macmillan, 2013.

The Barnabas Ministry. "Characteristics of Unhealthy, Abusive and Cultic Church Environments.” Diakses 12 Februari 2017, http://www.barnabasministry.com/recovery-characteristics.html 